\title{
Survey on Brinjal Leaf Mold in Manipur and Proving its Pathogenicity
}

\author{
Prashant*, R.K. Tombisana Devi, N. Iboton Singh and Apswari Murasing \\ Central Agricultural University, Imphal, Manipur, India \\ *Corresponding author
}

\begin{abstract}
A B S T R A C T
\end{abstract}

\begin{tabular}{|l|}
\hline Ke y w or d s \\
Brinjal, \\
Leaf mold, Survey, \\
Pathogenicity study, \\
PDI. \\
\hline Article Info \\
\hline $\begin{array}{l}\text { Accepted: } \\
\text { 17 May } 2017 \\
\text { Available Online: } \\
\text { 10 June } 2017\end{array}$ \\
\hline \hline
\end{tabular}

Brinjal is an important vegetable crop grown all over the world. It is been affected by many diseases. Brinjal leaf mold is an important disease, causing the yield loss in Manipur. Present study is to know the distribution and severity in valley districts of Manipur. The highest disease severity was ranging between $21.40-41.25 \%$. The pathogenicity study was also conducted simultaneously.

\section{Introduction}

The eggplant or brinjal or aubergine (Solanum melongena L.) represents the non-tuberous group of Solanum species. Vavilov (1931) reported that India was the center of origin. It can be grown in almost all parts of India, all the year round.

It is being grown extensively in India, Bangladesh, Pakistan, China, Philippines, France, Italy and United States. Brinjal is highly productive and usually finds its place as the poor man's vegetable (Som and Maity, 2002) and fruits are rich source of minerals like $\mathrm{Ca}, \mathrm{Mg}, \mathrm{P}$ and fatty acids. Besides being used as important vegetable, eggplant has been extensively exploited in traditional medicine for treatment of many diseases (Khan, 1979; Kashyap et al., 2003). In a recent investigation in Manipur, a new type fungal disease was observed in several plants in districts of Manipur. The disease is suspected to be new in this region, seems to infect leaves of brinjal plants. The symptoms of leaf mold disease is characterized by the appearance of brown cottony growth in patches on the abaxial side of the leaf and the patches become dark brown when the disease advances and leads to defoliation.

The symptoms resembles with the typical leaf mold disease symptoms of tomato, causal organisms isolated were Cladosporium fulvum and Alternara sp. The disease has been reported before in China by Yi et al., (1998) (C. solanum) and Zheng et al., (2014) (C. oxysporum) in diseased plant and fruits of aubergine, so present investigation was carried out to identify the causal agent, to assess the severity of disease in Manipur state. 


\section{Materials and Methods}

Survey was conducted during November to February, 2014-15 at different locations in the valley districts of Manipur namely Bishnupur, Thoubal, Imphal East and Imphal West. Observations on the disease incidence and severity were recorded from randomly collected 10 plants from farmer field by following 0-3 scale as described by McKinney (1923) (Table 1):

Per cent disease index (PDI) was calculated by the following formula

$\mathrm{PDI}=\frac{\text { Sum of all numerical ratings }}{\text { Total number of leaves observed } X \text { maximum disease grade }} \times 100$

Diseased leaf samples were collected from the field and brought to the laboratory.

The mold growth on the lower surface was scraped and aseptically transferred to potato dextrose agar (PDA) slants. These test tubes were incubated at $26 \pm 2^{\circ} \mathrm{C}$.

The fungal culture was purified by hyphal tip cut method (Tutte, 1969). The pure culture was maintained on freshly prepared potato dextrose agar slants.

The pure culture was maintained inside the refrigerator at $4^{\circ} \mathrm{C}$ and periodically sub cultured to fresh medium throughout the experimental period.

Pathogenicity test was conducted by following the method as described by Koch (1876). Healthy matured brinjal leaves were collected washed with the sterile water thoroughly and inoculated with the conidial suspension $(1 \mathrm{x} 108 \mathrm{cfu} / \mathrm{ml})$ by spore spray method and placed in a moist chamber at $26 \pm 2^{\circ} \mathrm{C}$ for 48 hours. Control leaves were sprayed only with sterile distilled water (Fig. 2).

\section{Results and Discussion}

The brinjal leaf mold was found to be well distributed in the surveyed valley districts of Manipur, as the crop is grown as both as perennial as well as annual crop. The disease was mainly observed during winter months, so present study was conducted to know its severity in the valley districts of Manipur.

Table 3 shows that the disease severity ranged from 21.40 to $41.25 \%$. The maximum disease incidence was recorded during the month of February in Thoubal $(41.25 \%)$, followed by Bishnupur (40.24\%), Imphal West (39.10\%) and Imphal East (37.70\%) respectively.

The district wise distribution and intensity of disease was found maximum in Bishnupur district followed by Imphal West and least disease intensity was recorded in Imphal East $(31.50 \%)$. The increase in disease incidence might be due to low temperature, high humidity and moist weather and less sunshine hours.

The present findings are in accordance with the findings of Mishra and Mishra (2012) who reported that the Cladosporium fulvum was present on both plant and fruit of eggplant and generally occurred during the month of November to May.

The diseased samples collected from the surveyed areas were brought to the laboratory for isolation. Repeated isolation Cladosporium fulvum Cooke was consistently found to be associated with the leaf mold disease of brinjal.

The fungus was identified by comparing with relevant monographs. The culture was maintained in PDA slants and stored in refrigerator at $4^{\circ} \mathrm{C}$ by sub culturing time to time for further use during studies. 
Table.1 Disease severity scale

\begin{tabular}{ll}
\hline Disease grade & Disease intensity on leaf \\
\hline 0 & No disease \\
0.75 & Very Slight \\
1 & Slight \\
2 & Moderate \\
3 & Abundant \\
\hline
\end{tabular}

Table.2 Meteorological data indicating actual monthly rainfall, number of rainy days, mean relative humidity, maximum and minimum air temperature and bright sunshine hours during survey period of disease occurrence (October 2014 - March 2015)*

\begin{tabular}{|l|l|l|l|l|l|l|}
\hline \multirow{2}{*}{ Month } & Total & \multicolumn{2}{|c|}{$\begin{array}{c}\text { Mean relative humidity } \\
\text { rainfall }\end{array}$} & \multicolumn{2}{|c|}{$\begin{array}{l}\text { Mean air temperature } \\
(\mathbf{m m})\end{array}$} & $\begin{array}{l}\text { Mean daily bright } \\
\text { sunshine (hours) }\end{array}$ \\
\cline { 3 - 7 } & Morning & Evening & Maximum & Minimum & \\
\hline October & 29.0 & 91.0 & 63.5 & 29.2 & 17.1 & 6.7 \\
\hline November & 0.0 & 85.2 & 53.9 & 28.0 & 11.7 & 8.0 \\
\hline December & 0.0 & 89.3 & 56.3 & 23.4 & 6.2 & 7.0 \\
\hline January & 46.6 & 87.2 & 51.0 & 22.7 & 7.4 & 7.5 \\
\hline February & 17.0 & 85.6 & 43.8 & 24.7 & 6.7 & 6.9 \\
\hline March & 21.3 & 77.7 & 42.5 & 28.5 & 11.0 & 7.1 \\
\hline
\end{tabular}

Table.3 Disease severity in different valley districts of Manipur

\begin{tabular}{lllllll}
\hline \multirow{2}{*}{ District } & \multicolumn{9}{l}{ Average disease severity (\%) } & & March \\
\cline { 2 - 7 } & October & November & December & January & February & March \\
\hline Bishnupur & 26.55 & 30.10 & 35.30 & 36.44 & 40.24 & 34.33 \\
Thoubal & 22.26 & 28.30 & 33.45 & 36.33 & 41.25 & 35.70 \\
Imphal East & 21.40 & 28.00 & 34.40 & 35.40 & 37.70 & 32.10 \\
Imphal West & 24.50 & 29.30 & 33.45 & 36.70 & 39.10 & 36.20 \\
\cline { 2 - 7 } Mean & $\mathbf{2 3 . 6 7}$ & $\mathbf{2 8 . 9 2}$ & $\mathbf{3 4 . 1 5}$ & $\mathbf{3 6 . 2 1}$ & $\mathbf{3 9 . 5 7}$ & $\mathbf{3 4 . 5 8}$ \\
\hline
\end{tabular}

* Weather data ICAR-RCNEHR-Manipur center.

Fig.1 Symptoms of leaf mold disease. 1a. Infected plant and 1b.infected leaf with black patches under the surface of leaf

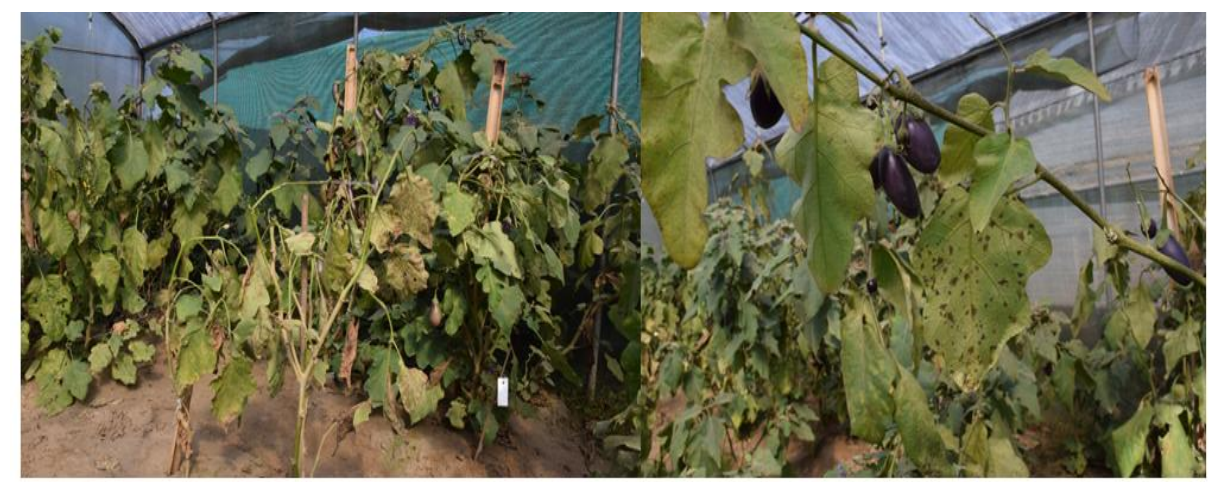


Fig.2 Datached leaf assey showing symptoms of leaf mold (pathogenicity test)

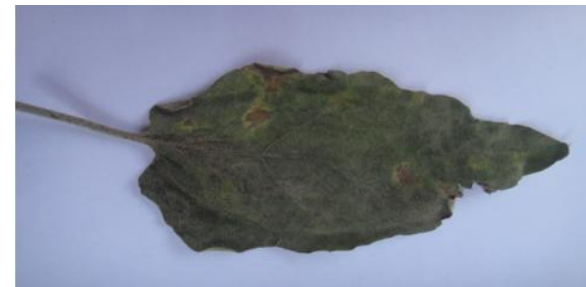

When the isolated fungus from the diseased samples was artificially inoculated on the healthy excised leaves of brinjal, it could induce characteristic symptoms of the disease after 7 days of inoculation (Fig. 1). On reisolation, the same fungus was found and thus it proves the pathogenicity of Cladosporium fulvum Cooke. The present findings are in accordance with the findings of Pandey and Pandey (2001) and Zheng et al., (2014) who reported the association of Cladosporium sp. in diseased plant and fruits of aubergine.

At present the disease is of minor economic importance in this region, but it may pose serious threat to pomegranate as symptoms are now prevalent in many gardens of brinjal. It was also observed that the cultivation of brinjal year around and presence of perennial brinjals in localities, that serves as source of inoculum. Further studies are needed to understand about this disease.

\section{References}

Kashyap, V., Kumar S., Collonier, C., Fusari, F., Haicour, R., Rotino, G.L., Sihachak, R.D., and Rajam, M.V. 2003. Biotechnology of eggplant. Scientia Hort., 97(1): 1-25.

Khan, R. 1979. Solanum melongena and its ancestral forms. In kawkes J.C., Lester J.G. and skelding A.D. (Ed.). Biol. Taxonomy Solanaceae: 629-638. Linnean Society of

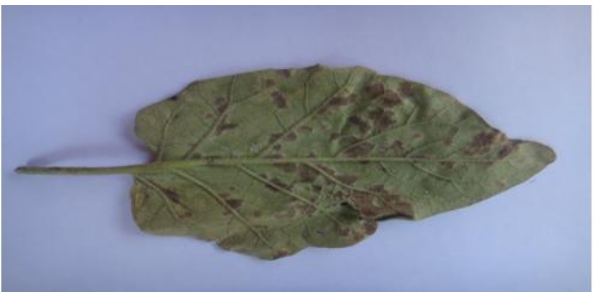

London Academic Press, London, pp. 629635.

Koch, R. 1876. In: Agrios, G.N. (ed) Plant Pathology. 5thedn. Academic Press, San Diego, California, pp. 26-27.

Mckinney, H.H. 1923. Influence of soil temperature and moisture on the infection of wheat seedlings by Helminthosporium sativum. J. Agric. Res., 26: 95-217.

Mishra, A.K. and Mishra, V.K. 2012. Field survey for some fungal diseases on eggplant. Intern. Multidiscip. Res. J., 2(9): 23.

Pandey, A. and Pandey, B.N. 2001. Fungal diseases on brinjal in Bareilly region. $A d v$. Plant Sci., 14(1): 99-104.

Som, M.G. and Maity, J.K. 2002. Brinjal Vegetable Crops, In: Bose, T.K., Kabir, J., Maity, 5. T.K., Parthasarthy, V.A. and Som, M.G., 3rd edn., Naya Prokash Publishers, Kolkatta, pp. 265-344.

Tutte, J. 1969. Plant pathological methods Fungi and bacteria. Burgess publishing company, U.S.A., pp 229.

Vavilov, N.I. 1931. The role of Central Asia in the origin of cultivated plants. Bull. Appl. Bot., 26(3): 3-44.

Yi, Z.Z., Hua, P.H., Long, L.Y. and Hong, Z. 1998. Taxonomy of Cladosporium in China VII. Mycosystema, 17(1): 4-6.

Zheng, C., Liu, Z.H., Tang, S.S., Lu, D. and Huang, X.Y. 2014. First report of leaf spot caused by Cladosporium oxysporum on greenhouse eggplant in China. Plant Dis., 98(4): 566.

\section{How to cite this article:}

Prashant, R.K. Tombisana Devi, N. Iboton Singh and Apswari Murasing. 2017. Survey on brinjal leaf mold in Manipur and proving its Pathogenicity. Int.J.Curr.Microbiol.App.Sci. 6(6): 1070-1073. doi: https://doi.org/10.20546/ijcmas.2017.606.123 